\title{
HUBUNGAN PENGETAHUAN ORANG TUA TENTANG FAKTOR RISIKO KANKER DENGAN SIKAP PENCEGAHAN KANKER
}

\author{
Nuraini Hakim ${ }^{1}$, Feni Amelia Puspitasari ${ }^{2}$ \\ 1. Akademi Keperawatan Manggala Husada \\ 2. Akademi Keperawatan POLRI \\ 3. \\ E-mail: nuraini.hakim85@gmail.com
}

\begin{abstract}
Abstrak
Kanker merupakan kumpulan sel abnormal yang terbentuk oleh sel-sel yang tumbuh secara terus-menerus, tidak terbatas, tidak terkoordinasi dengan jaringan sekitarnya, dan tidak berfungsi secara fisiologis (Price \& Wilson, 2005 dalam Nurhidayah, Hendrawati, Mediani, \& Adistie, 2016). Kasus kanker pada anak berjumlah 4,7\% dari kanker pada semua umur. Indonesia termasuk negara dengan kasus kanker tinggi yang diderita anak-anak. Orang tua dapat melakukan upaya pencegahan dengan mengenali faktor risiko penyebab kanker. Pencegahan kanker perlu dilakukan untuk menekan jumlah morbiditas dan mortalitas kanker. Upaya yang dilakukan untuk mencegah penyakit kanker salah satunya dengan menghindari faktor risiko pencetus kanker. Studi pendahuluan sebelumnya didapatkan pengetahuan orang tua tentang faktor risiko kanker tergolong cukup baik, namun belum ada penjelasan mengenai hubungannya dengan sikap pencegahan kanker yang dilakukan orang tua kepada anak. Penelitian ini bertujuan mengetahui hubungan antara pengetahuan orang tua dengan sikap pencegahan kanker pada anak. Desain penelitian ini menggunakan deskriptif cross sectional untuk mengetahui tingkat pengetahuan orang tua tentang faktor risiko kanker pada anak, dan hubungannya dengan sikap pencegahan kanker pada anak. Analisis yang digunakan adalah menggunakan uji chi square. Hasil penelitian univariat didapatkan tingkat pengetahuan sebagian besar responden adalah baik, dan sikap terhadap pencegahan kanker positif. Hasil analisis bivariat didapatkan tidak ada hubungan antara pengetahuan orang tua dengan sikap pencegahan kanker (pvalue: 0,396; $p>0,05$ ). Rekomendasi dari penelitian ini adalah agar orang tua tetap meningkatkan wawasan seputar kanker pada anak dan mengaplikasikan upaya pencegahan kanker dalam kehidupan sehari-hari.
\end{abstract}

Kata kunci: faktor risiko kanker, kanker pada anak, kanker

\begin{abstract}
Cancer is a collection of abnormal cells formed by cells that grow continuously, not limited, not coordinated with surrounding tissues, and not physiological functioning (Price \& Wilson, 2005 in Nurhidayah, Hendrawati, Mediani, $\&$ Adistie, 2016). The case of cancer in children amounted to $4.7 \%$ of cancer at all ages. Indonesia is a country with high cancer cases suffered by children. Parents can make preventive efforts by identifying cancer-causing risk factors. Cancer prevention needs to be done to suppress the amount of morbidity and mortality of cancer. Efforts undertaken to prevent cancer by avoiding the risk factors of cancer-triggers. Preliminary study obtained parents ' knowledge about the risk factor of cancer is quite good, but there is no explanation about its relationship with the cancer prevention attitude that parents do to the child. This research aims to determine the relationship between parents ' knowledge and the prevention of cancer in children. The design of this research uses a descriptive cross sectional to figure out the knowledge level of parents on cancer risk factors in children, and its relation to the attitude of cancer prevention in children. The analysis used is using the Chi square test. The results of the univariate study obtained the most level of knowledge of respondents was good, and attitudes towards the prevention of cancer was positive. Results of bivariate analysis obtained there are no relationship between parental knowledge with cancer prevention (pvalue: 0.396; $p>0.05$ ). The recommendation of this research is to keep parents improving their knowledge of cancer in children and applying cancer prevention efforts in daily life.
\end{abstract}

Keywords: risk factor of cancer, cancer in children, cancer 


\section{Pendahuluan}

Kanker adalah sekumpulan penyakit yang menyebabkan bertumbuhnya sel yang tidak normal di dalam tubuh secara tidak terkontrol dan dapat terjadi metastase ke organ lain (Potts dan Mandleco, 2012). Terminologi "Kanker Anak" seringkali disebutkan pada diagnosis kanker yang terjadi pada anak sampai usia 18 tahun (Kemenkes RI, 2015).

Menurut data Union for International Cancer Control (UICC), setiap tahun terdapat anak dengan diagnosis kanker yang berkisar 176.000 anak, sebagian besar berasal dari negara berpenghasilan rendah dan menengah. Meskipun kejadian kanker pada anak di seluruh dunia masih cukup jarang, namun kanker merupakan salah satu penyebab utama kematian 90.000 anak setiap tahunnya. Di negara berpenghasilan tinggi, kanker merupakan penyebab kedua terbesar kematian anak umur 5-14 tahun, setelah cedera dan kecelakaan. Sementara itu, di Indonesia terdapat sekitar 11.000 kasus kanker anak setiap tahunnya, dan terdapat sekitar 650 kasus kanker anak di Jakarta (Kemenkes RI, 2015).

Pengetahuan yang baik tentang kanker dapat mempengaruhi perilaku orang tua untuk melakukan upaya skrining dan pencegahan terhadap kanker. Namun, masih sedikit orang yang memahami permasalahan kanker. Hal tersebut sejalan dengan penelitian yang dilakukan oleh Gil, Yeropoli, Fish, Schnegg, dan Savitskil (2010) menjelaskan bahwa pengetahuan seorang wanita dewasa masih rendah mengenai faktor risiko kanker. Selain itu, penelitian yang dilakukan Adlard dan Hume (2003) menyatakan bahwa orang dewasa pada umumnya memiliki pengetahuan yang rendah terhadap kanker, kecuali pada individu yang memiliki riwayat keluarga dengan kanker.

Menurut Kemenkes RI (2016) upaya pencegahan kanker dapat pula dilakukan dengan menerapkan Perilaku Hidup Bersih dan Sehat (PBHS), sehingga mampu mengurangi risiko terserang kanker. Perilaku yang perlu diterapkan antara lain melakukan aktivitas fisik secara benar, teratur dan terukur; makan makanan bergizi dengan pola seimbang, cukup buah dan sayur; serta mengelola stres dengan tepat dan benar. Perilaku hidup bersih dan sehat merupakan salah satu program yang dicanangkan oleh pemerintah untuk mencapai MDGS pada tahun 2015. PHBS adalah segala kegiatan yang dilakukan dengan kesadaran sebagai hasil dari proses pembelajaran, sehingga dapat membantu keluarga dan masyarakat berperan aktif dalam menjaga kesehatan sertaterlibat dalam program kesehatan masyarakat (Kemenkes RI, 2018). Sikap positif orang tua terhadap upaya pencegahan penyakit 
dapat berpengaruh terhadap pengurangan kejadian kanker pada anak.

Berdasarkan penelitian yang dilakukan oleh penulis tahun 2018 di PAUD wilayah Jakarta Timur, didapatkan pengetahuan orang tua mengenai faktor risiko kanker tergolong cukup baik. Namun, dari hasil studi literatur belum ditemukan penelitian mengenai hubungan tingkat pengetahuan orang tua mengenai faktor risiko kanker pada anak dengan sikap pencegahan penyakit kanker. Berdasarkan uraian tersebut, maka penulis tertarik untuk mengidentifikasi hubungan tingkat pengetahuan orang tua tentang faktor risiko kanker pada anak dengan sikap pencegahan kanker yang dilakukan orang tua terhadap anakanaknya.

\section{Tinjauan Teori}

\section{Pengertian}

Kanker adalah sekumpulan penyakit yang disebabkan oleh bertumbuhnya sel-sel jaringan tubuh yang tidak normal. Sel-sel kanker akan berkembang dengan cepat, tidak terkendali, dan akan terus membelah diri. Selanjutnya, sel kanker akan menyerang ke jaringan sekitarnya dan terus menyebar (metastase) melalui jaringan ikat, darah, limfatik, serta menyerang organ-organ penting dan saraf tulang belakang (Potts dan mandleco, 2012 \& National Cancer Institute, 2015).

\section{Faktor yang Mempengaruhi Sikap}

Faktor yang mempengaruhi sikap menurut Ali (2011) dan Edunet (2017):

a) Lingkungan sosial

Interaksi sosial dapat berpengaruh terhadap sikap seseorang. Setiap kehidupan bermasyarakat memiliki sekelompok orang yang menginginkan hidup harmonis, sehingga dapat dijadikan referensi bagi individu dalam bersikap di suatu komunitas.

b) Pengalaman pribadi

Pengalaman pribadi menjadi dasar pembentukan sikap seseorang, terlebih jika diikuti dengan pelibatan emosi didalamnya.

c) Media

Media sangat bermafaat dalam komunikasi. Melalui televisi, media massa, dan internet orang dapat memperoleh informasi yang akhirnya mempengaruhi keyakinan, nilai, dan sikap seseorang.

d) Lembaga pendidikan dan lembaga agama

Lembaga pendidikan dan agama yang diikuti oleh seseorang merupakan dasar pembentukan sikap yang didasarkan pada moral dan aturan yang jelas, sehingga mampu membentuk pemahaman dan sikap. 
e) Faktor Fisik

Kondisi fisik seseorang, status gizi, kesehatan, dan vitalitas tubuh akan berpengaruh terhadap perkembangan hidup yang normal. Hal ini turut mempengaruhi pada sikap dan perilaku seseorang

f) Ekonomi dan pekerjaan

Status ekonomi, penghasilan, dan pekerjaan seseorang dapat membentuk sikap terhadap suatu objek.

\section{Metodologi}

Penelitian ini menggunakan desain deskriptif, yaitu penelitian yang bertujuan untuk mengeksplorasi suatu fenomena (Notoadmojo, 2012). Desain ini menggunakan pendekatan cross sectional yang bertujuan mengetahui hubungan tingkat pengetahuan orang tua tentang faktor risiko kanker pada anak, dan hubungannya dengan sikap pencegahan kanker. Analisis uji bivariat menggunakan uji chisquare.

\section{Hasil Penelitian}

\section{Karakteristik Ibu dan Anak}

Karakteristik ibu meliputi pendidikan terakhir, penghasilan, dan riwayat kanker di keluarga. Karakteristik anak meliputi usia, jenis kelamin, dan tingkat pendidikan. Berikut ini gambaran karakteristik ibu dan anak.
Tabel 4.1

Distribusi Karakteristik Respoden

Berdasarkan Pendidikan Terakhir, Penghasilan Keluarga, Riwayat

Kanker, Usia Ibu, Jenis Kelamin, Usia anak, dan Tingkat pendidikan di Jakarta, Tahun 2019

$$
(\mathrm{n}=55)
$$

\begin{tabular}{lcc}
\hline \multicolumn{1}{c}{ Variabel } & N & $\%$ \\
\hline Karakteristik Ibu & & \\
1. Pendidikan Ibu & & \\
a. Pendidikan SD-SMP & 7 & 12,7 \\
b. Pendidikan SMA & 25 & 45,5 \\
c. Pendidikan S1 & 23 & 41,8
\end{tabular}

2. Penghasilan Keluarga

$\begin{array}{lll}\text { a. 2-3 juta } & 21 & 38,2 \\ \text { b. Lebih dari 3-4 juta } & 7 & 12,7 \\ \text { c. lebih dari 4-5 juta } & 9 & 16,4 \\ \text { d. lebih dari 5 juta } & 18 & 32,7\end{array}$

3. Riwayat Kanker di keluarga

$\begin{array}{llc}\text { a. Ada } & 3 & 5,5 \\ \text { b. Tidak Ada } & 52 & 45,5\end{array}$

Karakteristik Anak

4. Jenis Kelamin
a. Laki-laki

b. Perempuan

5. Usia Anak

$\begin{array}{llcl}\text { a. } & 1-6 & 10 & 18,2 \\ \text { b. } & 7-12 & 36 & 65,5 \\ \text { c. } & 13-18 & 9 & 16,4\end{array}$

6. Tingkat pendidikan

$\begin{array}{llcc}\text { a. belum sekolah } & 11 & 20 \\ \text { b. TK } & 11 & 20 \\ \text { c. SD } & 20 & 36,36 \\ \text { d. } & \text { SMP-SMA } & 13 & 23,63\end{array}$

Berdasarkan tabel 4.1 di atas dapat diketahui bahwa karakteristik ibu sebagian besar berada pada tingkat pendidikan SMA, memiliki penghasilan keluarga sebesar 2-3 juta, dan sebagian besar tidak memiliki riwayat kanker dalam keluarga. 
Karakteristik anak dapat terlihat

sebagian besar jenis kelamin perempuan, berusia 7-12 tahun, dan sebagian besar berada di tingkat sekolah dasar

\section{Tingkat Pengetahuan Responden}

Tabel 2. Gambaran Skor Tingkat Pengetahuan di Jakarta Tahun 2019 $(\mathrm{n}=55)$

\begin{tabular}{lcccc}
\hline Variabel & Jumlah & $\begin{array}{c}\text { Presentase } \\
(\%)\end{array}$ & Min & Max \\
\hline $\begin{array}{l}\text { Skor 76- } \\
100 \text { (Baik) }\end{array}$ & 30 & 54,54 & 55 & 100 \\
Skor 50- & 25 & 45,45 & & \\
75 \\
$\begin{array}{l}\text { Cukup) } \\
\text { Skor <50 } \\
\text { (Kurang) }\end{array}$ & 0 & 0 & & \\
\end{tabular}

Berdasarkan tabel 2 di atas dapat diketahui bahwa orang tua yang memiliki skor 76-100 sebanyak 54,54 $\%$, skor 50-75 sebanyak 45,45 \%. Skor minimal adalah 55 dan skor maksimal adalah 100. Tabel di atas menjelaskan bahwa sebagian besar orang tua memiliki tingkat pengetahuan baik mengenai kanker.

\section{Skor Sikap Pencegahan Kanker}

Tabel 3. Gambaran Skor Sikap Pencegahan Kanker di Jakarta, Tahun

$$
2019(\mathrm{n}=55)
$$

Berdasarkan tabel 3 di atas dapat diketahui bahwa orang tua yang memiliki sikap positif tentang pencegahan kanker sebanyak 58,18 $\%$, dan sikap negatif tentang pencegahan kanker sebanyak 41,81 $\%$. Hal ini menunjukkan sebagian besar responden memiliki sikap positif terhadap pencegahan kanker.

\section{Hubungan Pengetahuan Orang tua dengan Sikap Pencegahan Kanker}

Tabel 4. Hubungan Pengetahuan dengan Sikap Pencegahan Kanker, di Jakarta, Tahun 2019 ( $\mathrm{n}=55)$

\begin{tabular}{|c|c|c|c|c|}
\hline & \multicolumn{2}{|c|}{ Sikap } & \multirow[b]{2}{*}{ Total } & \multirow[t]{2}{*}{$\mathrm{p}$ value } \\
\hline & Positif & Negatif & & \\
\hline \multicolumn{5}{|c|}{ Pengetahuan } \\
\hline Baik & 12 & 13 & 25 & 0,396 \\
\hline Cukup & 11 & 19 & 33 & \\
\hline Total & 23 & 32 & & \\
\hline \multicolumn{5}{|c|}{$\begin{array}{l}\text { Berdasarkan tabel } 4 \text { diketahui bahwa } \\
\text { tidak ada hubungan antara } \\
\text { pengetahuan tentang kanker dengan } \\
\text { sikap pencegahan } \\
(\text { pvalue }>0,05) \text {. }\end{array}$} \\
\hline
\end{tabular}

\section{Pembahasan}

\begin{tabular}{lccc}
\hline Variabel & Jumlah & Presentase (\%) & Mean \\
\hline Positif & 32 & $58,18 \%$ & 44
\end{tabular}


Hubungan Pengetahuan Tentang

Faktor Risiko Kanker dengan

Sikap Pencegahan Kanker

Berdasarkan hasil penelitian didapatkan gambaran hubungan pengetahuan dengan sikap pencegahan kanker mendapat pvalue 0,396. Angka tersebut menunjukkan tidak terdapat hubungan antara pengetahuan dengan sikap pencegahan kanker. Hasil penelitian ini menggambarkan pengetahuan responden tergolong baik, dan sikap terhadap pencegahan kanker tergolong positif namun tidak ditemukan hubungan antara dua variabel tersebut melalui analisis uji chi square. Penelitian ini sejalan dengan Rahmadi, Lestari, dan Yenita (2013) yang juga meneliti hubungan pengetahuan dengan sikap seseorang terhadap kesehatan, penelitian ini didapatkan proporsi siswa lebih tinggi yang memiliki sikap positif daripada sikap negatif $(32,6 \%: 28,6 \%)$, namun dari hasil uji statistik menunjukkan tidak terdapat hubungan yang bermakna antara pengetahuan dengan sikap (pvalue: 1,000). Hasil ini didukung pula oleh penelitian yang dilakukan Abdullah, Tangka, dan Rottie (2013) bahawa tidak ada hubungan antara pengetahuan dan sikap deteksi dini terhadap kanker.
Faktor yang mempengaruhi tidak sejalannya antara pengetahuan dengan sikap seseorang adalah karena terdapat faktor lain yang mempengaruhi sikap seseorang. Menurut Ali (2011) sikap dapat dipengaruhi oleh media, lingkungan sosial, pekerjaan, ekonomi, dan lembaga pendidikan dan agama. Hal yang memungkinkan menjadi penyebab tidak ada hubungan antara pengetahuan dengan sikap adalah faktor ekonomi dan pekerjaan. Sebagian besar responden sebagai ibu rumah tangga dan mendapatkan penghasilan keluarga di bawah upah minimum regional (UMR) sekitar 2-3 juta. Status ekonomi, penghasilan, dan pekerjaan seseorang dapat membentuk sikap terhadap suatu objek. Apabila status ekonomi baik, dapat berpeluang memiliki sikap positif terhadap suatu objek. Sejalan dengan Gustiana, Dewi, dan Nurchayati (2014) menjelaskan dari hasil penelitiannya didapatkan terdapat hubungan antara status ekonomi dengan sikap pencegahan kanker. Responden yang memiliki status ekonomi baik, yaitu penghasilan melebihi UMR melakukan upaya pencegahan kanker dengan baik. 
Penelitian yang dilakukan oleh

Damailia dan Oktavia (2015) menjelaskan terdapat hubungan antara pengetahuan dengan sikap pencegahan kanker serviks. Penelitian tersebut menjelaskan responden yang memiliki pengetahuan baik maka berbanding lurus dengan sikap positif dalam melakukan upaya pencegahan kanker serviks.

\section{Simpulan}

1. Karakteristik ibu sebagian besar berada pada tingkat pendidikan SMA, memiliki penghasilan keluarga sebesar 2-3 juta, dan tidak memiliki riwayat kanker dalam keluarga.

2. Karakteristik anak dapat terlihat sebagian besar jenis kelamin perempuan, berusia 7-12 tahun, dan sebagian besar belum berada pada tingkat pendidikan SD .

3. Tingkat pengetahuan orang tua tentang faktor risiko kanker tergolong baik

4. Sikap pencegahan orang tua terhadap kanker tergolong positif

5. Tidak terdapat hubungan antara pengetahuan dengan sikap pencegahan kanker pada anak

\section{Saran}

1. Orang tua hendaknya mempertahankan pengetahuan yang sudah baik dan lebih meningkatkan wawasan mengenai penyakit kanker pada anak dengan banyak membaca buku kesehatan, browsing internet, dan memanfaatkan informasi kesehatan seputar kanker dari media massa.

2. Orang tua hendaknya mempertahankan dan meningkatkan sikap pencegahan kanker yang sudah baik dan terus mengaplikasikan pola hidup sehat guna mencegah terjadinya kanker pada anggota keluarga.

\section{Kepustakaan}

Abdullah, N., Tangka, J., \& Rottie, J. (2013). Hubungan pengetahuan tentang kanker payudara dengan cara periksa payudara sendiri pada mahasiswi semester iv program studi ilmu keperawatan fakultas kedokteran universitas sam ratulangi. ejournal keperawatan (eKp) Volume 1. Nomor 1.

Adlard, J.W. \& Hume, M.J. (2003). Cancer Knowledge of the General Public in the United Kingdom: Survey in a Primary Care Setting and Review of the Literature. Clinical oncology, 15, 4, 174-180.

Ali, O. (2011). Factors That Determine Our Attitude. Diakses dari https://mylittleblackpen.wordpress. com/2011/08/28/factors-thatdetermine-our-attitude/ tanggal 18 Februari 2019 
Damailia, H.T. \& Oktavia, T.R. (2015).

Faktor-faktor determinan deteksi dini kanker serviks melalui metode pap smear pada pasangan usia subur (pus). Jurnal Kesehatan Gaster, Volume 12, No. 2.

Edunet (2017). Factors influencing attitude. Diakses dari https://iedunote.com/termsservice-conditions tanggal 18 $\underline{\text { Februari } 2019}$

Gil KM, Yeropoli S, Fish B, et al (2010). Knowledge of cancer risk factors. J Clinical Oncol, 28, 15. https://doi.org/10.1200/JCO.2008 .20 .9288

Gustiana, D., Dewi, Y.I., Nurchayati, S. 2014. Faktor-faktor yang berhubungan dengan perilaku pencegahan kanker serviks pada wanita usia subur. JOM PSIK. 1(2): 2-8.

Kemenkes RI. (2015). Riset Kesehatan

Dasar 2015. diunduh pada 10 April

2019 dari www.depkes.go.id

Kemenkes RI. (2016). Kendalikan kanker pada anak. diunduh pada 15 April 2018 dari www.depkes.go.id

Kemenkes RI. (2018). Perilaku hidup bersih dan sehat.

www.depkes.go.id

National Cancer Institute (2015).

Research on Screening and

Early Detection Is Critical to

Progress against Cancer.

diunduh pada 9 Maret 2018 dari

https://www.cancer.gov/research lareas/screeningdated

Notoatmojo. (2012). Pengantar

Pendidikan Kesehatan Dan Ilmu

Perilaku Kesehatan.

Yogyakarta: Andi offset. for children and their families.

3rd edition. USA: Delmar

Cengage Learning

Rahmadi, A., Lestari, Y., \& Yenita. (2013). Hubungan Pengetahuan dan Sikap Terhadap Rokok Dengan Kebiasaan Merokok Siswa SMP di Kota Padang. Jurnal Kesehatan Andalas, (2), 1. 